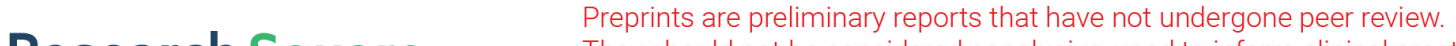 They should not be considered conclusive, used to inform clinical practice, or referenced by the media as validated information. \\ Fabrication of Al203-coated $\mathrm{BiFeO3}$ particles and fine-grained ceramics with improved electric properties
}

\section{Peijia Bai}

Kunming Institute of Precious Metals

\section{Yutong Li}

Kunming Institute of Precious Metals

\section{Gang Wang}

Kunming Institute of Precious Metals

Jiao Han

Kunming Institute of Precious Metals

\section{Yongxing Wei}

Xi'an technological University

\section{Mingwei Li}

Kunming Institute of Precious Metals

\section{Duan Mao}

Kunming Institute of Precious Metals

Yiming Zeng ( $\square$ zengym0871@126.com )

Kunming Institute of Precious Metals https://orcid.org/0000-0003-4046-4320

\section{Research Article}

Keywords: BiFeO3, Al2O3-coating, Microstructure, Electric properties

Posted Date: July 14th, 2020

DOl: https://doi.org/10.21203/rs.3.rs-40088/v2

License: (c) (1) This work is licensed under a Creative Commons Attribution 4.0 International License. Read Full License

Version of Record: A version of this preprint was published at Journal of Materials Science: Materials in Electronics on October 26th, 2020. See the published version at https://doi.org/10.1007/s10854-02004685-w. 
The authors have withdrawn this preprint from Research Square 